\title{
Klaudia Golon
}

http://orcid.org/0000-0002-5229-4499

Uniwersytet Gdański

klaudia.golon@wp.pl

DOI: $10.35765 /$ pk.2021.3504.11

\section{Muzeum jako przestrzeń narracji o Korei}

\section{STRESZCZENIE}

Artykuł stanowi analizę wystawy Splendor $i$ finezja. Duch $i$ materia $w$ sztuce Korei, która prezentowana była w Muzeum Narodowym w Warszawie na przełomie 2019 i 2020 r. Autorka proponuje jako metodę analizy studia nad narracją - przeniesione - zgodnie z propozycją Małgorzaty Czermińskiej z literaturoznawstwa na grunt wystawy muzealnej. Wychodząc od założeń klasycznego muzealnictwa, poprzez wypowiedzi osób odpowiadających za stworzenie wystawy, aż do analizy jej tytułu, autorka próbuje zbliżyć się do najważniejszego - filologicznej interpretacji narracji muzealnej wystawy. W artykule ujawnia się zarazem wiedza proponowana zwiedzającym, jak i sposób ujęcia, w tym - tabuizacja pewnych tematów.

SŁOWA KLUCZE: narracja muzealna, Korea, narracja ciągła, wystawa, przestrzeń muzealna

\section{AB STRACT}

\section{A Museum’s Narrative Space about Korea}

The article analyzes the exhibition titled Splendor $i$ finezja. Duch $i$ materia $w$ sztuce Korei, which was presented at the National Museum in Warsaw at the turn of 2019 and 2020. The author proposes a narrative study as a method of analysis, transferred, as proposed by Małgorzata Czermińska, from literary studies to a museum exhibition. Starting from the classical assumptions of museology, through statements of the people responsible for creating the exhibition, to the analysis of its title, the author tries to get closer to the most important, philological interpretation of the museum exhibition narrative. The article reveals the knowledge proposed to the visitors and the way of presenting it, including tabooing certain topics.

KEYWORDS : museum narrative, Korea, continuous narrative, exhibition, museum space 


\section{Założenia muzealnictwa}

Wydawać by się mogło, że nie ma nic prostszego niż wybranie kilku eksponatów z jednego muzeum i przeniesienie ich do drugiego w ramach wystawy czasowej. Nie trzeba jednak nikogo przekonywać, że tworzenie wystaw raczej tak nie działa. Każda wystawa ma coś do przekazania, jest efektem współpracy wielu ludzi i godzin poświęconych na wymyślanie jej koncepcji. Wystawy mają oczywiście swoje własne założenia, ale tworzenie wystaw czasowych charakteryzuje się innymi ogólnymi założeniami teoretycznymi, które trzeba wziąć pod uwagę w procesie organizacji. I tak wystawę czasową determinuje według Zdzisława Żygulskiego

atrakcyjny i monograficzny charakter pokazu, czas zwiedzania nie przekraczający 2 godzin (jest to wypróbowany czas przeciętnej projekcji filmowej), konstrukcja dynamiczna stopniująca wrażenia, prowadząca do kulminacji, a następnie do wygaszenia wrażeń, umiejętność operowania masami zwiedzających (Żygulski, 1990, s. 9).

Każdą wystawę czasową można odnieść do tych założeń i sprawdzić, czy spełnia podstawowe cechy, które udało się wyodrębnić muzealnikom.

Innym ważnym aspektem wystaw czasowych są powody ich powstawania. Wystawy czasowe obecne są w większości muzeów, także specjalistycznych czy tematycznych. Mogą całkiem dosłownie dotyczyć czasu, to znaczy wpasowywać się w wydarzenia roku kalendarzowego jak rocznice czy święta, mogą to być wystawy podróżujące, dla których znalazło się miejsce w danym muzeum - wielkim plusem wystaw czasowych jest różnorodność, choć oczywiście powinny wpisywać się w założenia miejsca, w którym są prezentowane. Wystawy nie są jednak neutralne i o wartościach związanych z nimi tak pisze Jerzy Świecimski:

Podjęcie tematu wartości leżących u podłoża wystaw muzealnych uzasadnione jest okolicznością, że wystawy te nigdy nie powstawały przypadkowo, lecz tworzone były zawsze „w imię czegoś”, lub „ze względu na coś” i że owo „coś”, jako moment inspirujący każde powstanie wystawy wiązało się zawsze z jakąś wartościowością, lub samo uznawane było za jakąś wartość (Świecimski, 1994, s. 38).

Analizując wystawę muzealną, należy się zastanowić, z jakich powodów jest ona obecna w danym muzeum oraz wziąć pod uwagę okoliczności towarzyszące. Wystawa nie pojawia się bowiem w próżni i nie tylko przedstawiana jest $\mathrm{w}$ danym miejscu, $\mathrm{w}$ danym czasie, ale także powoduje budowanie dalekich asocjacji w świadomości odwiedzającego. W szerokiej skali można by się zastanawiać, jak poszczególne wystawy czasowe wpływają 
na swój odbiór, czy jak wystawy stałe, czy nazwa muzeum wpływa na odbiór wystawy czasowej. Można rozważać psychologiczne i pamięciowe - zarówno w kontekście wspomnień przyniesionych do muzeum, jak i z niego wyniesionych - aspekty narracji muzealnych (Yaxi Liu, 2000) czy badać zaangażowanie zwiedzającego, a także bezpośrednie interakcje z wystawą, jeśli daje takie wirtualne możliwości. Najważniejsze jest jednak założenie, że każda wystawa tworzona jest, aby przekazać wartości, i na każdym etapie analizy wystawy należy się zastanawiać, jakie są to wartości.

\section{Przed wystawą}

Wystawa Splendor ifinezja. Duch i materia w sztuce Korei to efekt współpracy Muzeum Narodowego w Warszawie oraz Koreańskiego Muzeum Narodowego w Seulu. Została zorganizowana z okazji trzydziestolecia nawiązania stosunków dyplomatycznych pomiędzy Republiką Korei i Rzeczpospolitą Polską. Wystawa wpisywała się w inne wydarzenia upamiętniające i niejako je wieńczyła, gdyż można było ją podziwiać w Muzeum Narodowym od 11 października 2019 r. do 12 stycznia 2020 r. Splendor $i$ finezja. Duch i materia w sztuce Korei zapowiadana była przez zespół kuratorski Koreańskiego Muzeum Narodowego jako pierwsza tak duża (katalog wystawy zawiera 250 artefaktów) i absolutnie unikatowa wystawa koreańskiego dziedzictwa kulturowego w całej Europie Środkowo-Wschodniej. Wystawa była także kontynuacją współpracy pomiędzy muzeami zapoczątkowaną cztery lata wcześniej.

Koreańczycy sztukę polską mogli podziwiać w swoim kraju w roku 2015, gdy Muzeum Narodowe w Warszawie współpracowało z Koreańskim Muzeum Narodowym w Seulu nad wystawą Sztuka polska: Nieztomny duch (która była wariacją wystawy pokazywanej wcześniej w Pekinie). Zespół kuratorski zakładał, że obie wystawy ujawniają podobieństwa między dziejami Polski i Korei. Widział je m.in. w doświadczeniu wojen i oryginalności sztuki obu regionów:

[wystawa] odbiła się szerokim echem i wskazała na zaskakujące podobieństwa w dziejach Korei i Polski - wielokulturowość, doświadczenie licznych wojen i zdolność do stworzenia oryginalnej kultury. Mamy nadzieję, że prezentacja sztuki ze zbiorów Koreańskiego Muzeum Narodowego pogłębi relacje między naszymi krajami” (zespół kuratorski, ulotka wystawy).

Dzieje Korei i Polski bywają na tyle podobne, że w tekście Marii Poprzędzkiej można przeczytać: „Koreańczycy, z racji swojego położenia 
i historycznych doświadczeń nazywani są podobno «Polakami Dalekiego Wschodu»” (Poprzędzka, 2015, s. 57). Współcześnie buduje się paralele pomiędzy Polakami walczącymi z komunizmem, związanymi z tym protestami oraz walką Koreańczyków z autorytarnym rządem. Porównuje się też położenie geograficzne Korei - pomiędzy Chinami i Japonią oraz Polski - pomiędzy Niemcami i Rosją. Także szczególnie „doświadczenie licznych wojen” jest trafnym określeniem, choć wymagającym szczegółowych wyjaśnień. Stwierdzenia o „wielokulturowości” i „zdolności do tworzenia oryginalnej kultury" są bardzo niespecyficznymi kategoriami, którymi można próbować zbliżyć do siebie wiele różnych kultur. Trudno jednak rozstrzygnąć, czy podkreślanie podobieństw jest zabiegiem interkulturowym, PR-owym bądź dyplomatycznym. Wystawa powstała przecież z okazji rocznicy nawiązania stosunków dyplomatycznych. Być może jednak dla zwiedzających wystawę w Seulu podobieństwa historyczno-geograficzne były aż tak uderzające. Równocześnie te kategorie nie muszą się wykluczać. Zauważono podobieństwo i postanowiono je wykorzystać, być może zakładając, że skoro kulturowo (i to w szerokim znaczeniu tego słowa) Polska i Korea tak bardzo się różnią, to aby ułatwić odbiór wystawy, należy podkreślać możliwe podobieństwa.

\section{Stanowisko kuratorki}

Za projekt aranżacji wystawy odpowiadało studio Jaz Plus Architekci, którego scenografia została wybrana przez dyrektora Muzeum Narodowego. Główny kurator ze strony koreańskiej to Yang Seungmee, ze strony polskiej - Joanna Bojarska-Cieślik. Wykład wprowadzający w wystawę dostępny jest na stronie YouTube, w związku z czym warto sprawdzić, co na temat koncepcji wystawy miała do powiedzenia sama kuratorka. Zaczyna ona od wyjaśnienia znaczenia słowa „splendor”. Robi to w ciekawy sposób - odnosi je do polskiego sarmatyzmu. Następnie płynnie przechodzi do niewątpliwie najważniejszego artefaktu prezentowanego na wystawie, czyli złotej korony z Królestwa Silla. Opowiada także o wpływach taoizmu na kulturę i sztukę Korei w kontekście drugiej części tytułu wystawy Duch i materia. Warto zaznaczyć, iż ten wątek na samej wystawie był zupełnie niewidoczny i niewyjaśniony. Kuratorka w swojej wypowiedzi bardzo mocno podkreśla analogie pomiędzy historiami Korei i Polski oraz doświadczeniami mieszkańców tych krajów. Prelegentka postanowiła porównać wystawę Splendor $i$ finezja oraz wystawę Sztuka polska: Nieztomny duch pod względem liczby zabytków, instytucji biorących udział w wystawach ze strony polskiej i koreańskiej oraz instytucji wypożyczających zabytki na wystawę. Numeryczne porównanie wypada 
korzystniej dla strony polskiej i nie można oprzeć się wrażeniu, że zostało ono stworzone, aby się pochwalić, bo nie ma żadnej merytorycznej wartości. Kuratorka mówi, że Koreańskie Muzeum Narodowe jest największym muzeum Korei, posiada dziesięć oddziałów, ale z tego fragmentu wypowiedzi można wyprowadzić sugestię, że Polacy zrobili więcej niż Koreańczycy.

Stronie polskiej zależało bardziej na pokazaniu długowieczności koreańskiej kultury, ze strony koreańskiej pierwszą propozycją była wystawa tematyczna dotycząca uczonego urzędnika. Kuratorka mówi o chęci pogłębienia obrazu Korei, ponieważ, jej zdaniem, kojarzy się ona w Polsce z nowymi technologiami i samochodami. Jeżeli przyjrzeć się temu zagadnieniu bliżej, można dość do wniosku, że kulturowe postrzeganie Korei prawie nie istnieje wobec skali obecności kultury chińskiej (o tym wspomina kuratorka), technologicznie zaś Koreę niejako zasłania Japonia, która to w Polsce bardziej funkcjonuje jako symbol dynamicznego rozwoju nowoczesnych technologii (Citko, 2011). Wobec tego wystawa stara się pokazać i podkreślić odrębność oraz unikatowość sztuki koreańskiej.

Także pokazanie sztuki buddyjskiej było inicjatywą strony polskiej. Kuratorka wspomina na początku prelekcji, że koreańskie muzeum nie posiada zbiorów sztuki dwudziestowiecznej, ale mówi też, że strona polska nie za bardzo chciała pokazywać ten okres dziejów i że wyjaśni to dokładniej później; niestety tego nie robi. Łatwo się jednak domyślić, że niechęć spowodowana jest złożoną historią Korei w tym czasie, natomiast dlaczego kuratorka zapomina do tego wrócić - nie wiadomo. Poruszanie historii XX w. na wystawie wymagałoby skomplikowanych zabiegów na źródłach - sprowadzania ich z innych koreańskich muzeów czy szczegółowego tłumaczenia wielu aspektów historii. Patrząc na rozkład wystawy, byłby problem $\mathrm{z}$ umieszczeniem dodatkowych eksponatów $\mathrm{w}$ salach. Powstaje jeszcze jedno pytanie: czy znalazłyby się eksponaty wpisujące się w temat wystawy? Być może nie, gdyż np. jedną z tragedii Korei po zajęciu jej przez Japonię było to, że Japończycy wywieźli wiele zabytków. Joanna Rurarz precyzuje - „w zasadzie należałoby powiedzieć wręcz ukradziono wiele zabytkowych przedmiotów" (Rurarz, 2009, s. 332). Nie wolno zapomnieć także o stratach wojennych. Z jednej strony wyjaśnia to brak XX w. na wystawie, z drugiej - chronologicznie wystawa zaczyna się od najdawniejszych śladów ludzi na Półwyspie, jest wyraźnie rozciągnięta w przeszłość. Takie ucięcie jej w XIX w. pozostawia pewien niedosyt oraz rodzące się pytania i wątpliwości co do współczesności. Można by ten brak uzupełnić na dwa proste sposoby - informując, że niewspominanie o XX w. nie jest celowym, zaplanowanym zabiegiem, tylko Muzeum Koreańskie dysponuje artefaktami do początku XX w. To nie jest zbyt intuicyjne założenie dla odbiorcy, że instytucja, która posiada 
paleolityczne relikty, nie ma takich z XX w. Innym rozwiązaniem byłby jeden papirus z zarysem historycznym XX w. Przy czym należy dodać, że - znów - mógłby być problem z miejscem. Więcej pracy wymagałoby dodanie informacji do ulotek i albumu.

W kontekście wspominanych wcześniej skojarzeń należy się zastanowić, czy opowiadanie o historii Korei w XX w., a szczególnie o jej podziale, nie wprowadziłoby na wystawę współczesnego kontekstu politycznego. Odchodząc od zaznaczania podziału na Koreę Południową i Północną, co prawda odwraca się uwagę od politycznych uwarunkowań Półwyspu, które to prawdopodobnie są dużo bardziej kojarzone z Koreą niż technologia i samochody, i zwraca się ową uwagę na inne aspekty historii i kultury - zgodnie z zapowiedziami kuratorki.

\section{Znaczenia tytułu wystawy}

Aby być pewnym możliwie dokładnego zrozumienia wszystkich pojęć, które zawiera tytuł wystawy - Splendor i finezja. Duch i materia w sztuce Korei - najlepiej sprawdzić ich znaczenie w słowniku. O splendorze możemy przeczytać, że jest to „przepych, świetność, wspaniałość, blask; zaszczyt, honor” (Doroszewski), o finezji - „subtelność, delikatność, wyrafinowanie; precyzja” (Doroszewski). Wydaje się, że w kontekście kultury europejskiej słowa te razem idealnie opisywałyby sztukę barokową. Patrząc natomiast na kolejność prezentowania obiektów na wystawie, można dojść do wniosku, że w kulturze Korei splendor i finezja przeplatają się nieustannie. Doprecyzowuje rozumienie tytułu dyrektor Muzeum Narodowego w Warszawie w słowie wstępnym albumu o wystawie:

Słowo „splendor” odnosimy przede wszystkim do bezcennych zbiorów ze złota - zwłaszcza złotych koron (...); zaś słowo „finezja” wiążemy m.in. z przepięknymi seladonami i wyrobami z białej porcelany (Miziolek, 2019, s. 10).

Druga część tytułu wystawy brzmi Duch i materia $w$ sztuce Korei - na początku wystawy można się dowiedzieć o materiałach takich jak kamień, glina czy brąz. Ponieważ wystawa ma charakter chronologiczny, w każdej kolejnej sali materiały, z których powstawały eksponaty, będą pokazywały rozwój technologiczny ludności, która je wytwarzała.

Wpływ duchowości neokonfucjańskiej na sztukę Korei zaznacza dyrektor Muzeum Narodowego: 
Czy do tego sukcesu przyczynił się (...) neokonfucjanizm z takimi wartościami jak posłuszeństwo, lojalność, poszanowanie hierarchii, prostota i skromność? Starannie opracowany katalog wystawy jest świadectwem znaczącego wpływu wspomnianej ideologii na kulturę materialną. Finezyjna prostota przedmiotów, którymi otaczała się elita (...) ucieleśnia konfucjańskie ideały (Miziołek, 2019, s. 10-11).

Należy napisać, że zaprezentowany wyżej fragment wypowiedzi dobrze podsumowuje całą wystawę. Niezaprzeczalnie podkreślano długie trwanie konfucjanizmu czy raczej neokonfucjanizmu z założeniem, że jego wartości istotne są także w czasach współczesnych.

Podsumowując, tytuł Splendor i finezja. Duch i materia w sztuce Korei daje podstawy, aby zakładać, że będzie to wystawa bogata i różnorodna ale szczególnie i niezwykle złota. Nawet na okładkach ulotek wystawy widzimy złotą koronę oraz złotego Bodhisattwę Awalokiteśwarę. Dalej że na wystawie pojawi się to, co najlepszego Korea ma do zaoferowania i prawdopodobnie będzie miało to związek z życiem arystokracji i króla.

\section{Przestrzeń wystawy}

Wystawa Splendor i finezja. Duch i materia $w$ sztuce Korei prezentowana była w siedmiu salach, w układzie chronologicznym. W pierwszej sali znajdowały się artefakty z paleolitu czy epoki brązu. Ważne miejsce zajmowały w niej naczynia grobowe. W kolejnej sali podziwiać było można eksponaty z okresu Trzech Królestw. Najważniejszym artefaktem prezentowanym w tej sali była złota korona z Królestwa Silla - ta, która znajduje się na jednej z ulotek. Trzecia sala poświęcona była kulturze i sztuce buddyjskiej. Można było w niej zobaczyć liczne rzeźby Buddy i Bodhisattwy oraz naczynia rytualne. W sali czwartej pokazano seladony - specjalny typ ceramiki. Kolejna sala także przedstawiała koreańską ceramikę oraz białą porcelanę. W salach szóstej oraz siódmej szeroko prezentowano różnorodne eksponaty z okresu Joseon - od królewskich szat, poprzez zabytki związane z klasą urzędniczą, aż do naczyń przeznaczonych do przeprowadzania rytuałów na cześć przodków.

Jest to dobry moment, aby powrócić do założeń wystaw czasowych przedstawionych wcześniej i sprawdzić, czy wystawa Splendor i finezja. Duch i materia w sztuce Korei je spełnia. Można z pewnością stwierdzić, że wystawa ma atrakcyjny i monograficzny charakter - chociaż należy napisać, że pierwsza sala sprawia wrażenie pustej i niezachęcającej do dalszego zwiedzania, nawet pierwsza część drugiej sali nie jest jeszcze przekonująca - dopiero wydzielona część ze złotą koroną sprawia, że chce 
się zwiedzać dalej. Można napisać, że jest to pierwszy punkt kulminacyjny wystawy. Złoto korony niejako przenika do kolejnej sali - prezentowane posąi Buddy także są złote bądź powstawały z innych najlepszych materiałów i prezentują wysoki poziom artystyczny. Kolejne sale poświęcone ceramice i porcelanie obrazują część „finezja” z tytułu wystawy bez wątpienia ułożenie prezentacji spełnia zasadę stopniowania wrażeń i konstrukcji dynamicznej, gdyż po uspokojeniu odczuć w salach z ceramiką docieramy do najbogatszych i najbardziej różnorodnych sal (sześć i siedem) prezentujących najszersze spektrum eksponatów. To prawdziwy punkt kulminacyjny wystawy. Jest on jednak związany bezpośrednio z pierwszym najbardziej eksponowanym artefaktem - złotą koroną. Wyraźnie widać podkreślanie królewskości i długiego trwania tradycji monarszych. Na wystawie brakuje elementu wygaszenia wrażeń, gdyż dwie ostatnie sale wypełniono eksponatami do granic ich pojemności i chociaż jest tam plan i układ - sprawiają one wrażenie chaotycznych. Widać to szczególnie przy porównaniu sali szóstej z salami, w których są jedynie seladony, czy nawet z salą, w której prezentowana była sztuka buddyjska. Każda poprzednia sala skupiła się na jednym temacie czy nawet jednym rodzaju eksponatów, a ostatnie sale podejmują wiele tematów - od artefaktów królewskich, wraz z szatami, ozdobami i parawanami, poprzez zabytki związane z kaligrafią, klasą urzędniczą i arystokracją. Pomysł, aby przedstawić 500 lat różnych aspektów kultury i sztuki okresu Joseon (nawet jeśli ograniczony do eksponatów dotyczących koreańskich elit), wydaje się chybiony, wcześniej sama ceramika zajmuje dwie sale i nie można pozbyć się wrażenia, że lepszym rozwiązaniem byłoby skupienie ceramiki w jednej sali i dodanie jeszcze jednej sali dla eksponatów z Joseon.

Sala szósta zasługuje na bardziej szczegółowy opis. Od pozostałych różni się nie tylko liczbą eksponatów, ale także kolorem ścian - są czerwone. W pozostałych salach ściany są szare bądź ciemnoszare, poza częścią sali drugiej, gdzie eksponowana jest złota korona - to miejsce wyglądało jak osobna czarno-złota gablota. Kumulacja efektów, gęstość eksponatów i wyraźnie zauważalne staranie, aby sala szósta była najważniejszą salą całej wystawy, dawały jednak nieco przytłaczający rezultat.

$\mathrm{Z}$ nieco innej strony jako przytłaczającą można było odebrać liczbę seladonów i innych rodzajów ceramiki pokazywanej na wystawie. Chociaż eksponaty prezentowane były w dwóch salach przeznaczonych tylko dla nich, to, nie ujmując wartości i piękna poszczególnym niezwykłym wyrobom, było ich zbyt wiele, aby utrzymać uwagę i skupienie oglądającego. Któreś z kolei nefrytowozielone bądź białe naczynie prezentowane obok kolejnego zielonego bądź białego naczynia zaczyna niestety zlewać się z pozostałymi. Trzeba jednak zaznaczyć, że sale z ceramiką 
odznaczały się przestronnością i pewnym spokojem sprzyjającym skupieniu w przeciwieństwie do sali szóstej.

Podsumowaniem znaczenia dysproporcji pomiędzy salami z ceramiką i salami ze sztuką okresu Joseon są przywołane spostrzeżenia profesor Małgorzaty Czermińskiej:

Różnorodność pozwala zaspokoić potrzebę zmienności wrażeń, chłonięcia różnych bodźców, ponieważ są takie rodzaje ładu, które grożą nudą. Wówczas ratunkiem dla zwiedzającego jest szukanie różnorodności, taka postawa, by starać się dostrzec "nieporządek miły”, trochę twórczego chaosu (Czermińska, 2018, s. 7).

Na opisywanej wystawie zwiedzający nie musiał sam szukać ratunku prowadzono go tak, aby z sali grożącej nudą przeszedł do sali z najbardziej różnorodnymi eksponatami.

$\mathrm{Na}$ wystawie zdecydowanie prezentowano przedmioty, rytuały oraz życie wyższych warstw społecznych, i to już od najwcześniejszych czasów. Najbardziej eksponowanym artefaktem całej wystawy jest wspominana już kilkukrotnie korona z Królestwa Silla. Wydzielona za pomocą przygotowanych zasłon składających się ze złotych kwadratowych płytek oraz czarnego koloru ścian część sali, gdzie była ona prezentowana wraz z innymi złotymi eksponatami, ogromnie wyróżnia się spośród ciemnoszarych sal. Siła oddziaływania tej korony jest odczuwalna przez całą wystawę, zarówno za sprawą jej prezentacji - o tym, co widziało się wcześniej, po prostu się nie pamięta, jak i promowania jej w materiałach dodatkowych - znajduje się na okładach ulotek, które są utrzymane w eleganckiej złoto-czarnej stylistyce.

Ponadto warto zauważyć, że cała wystawa spełnia założenia systemu „witryny sklepowej” (Żygulski, 1990, s. 8), wprowadzonego ze względu na liczne zagrożenia, którym poddane są artefakty - wszystkie eksponaty (poza szatami królewskimi, które są replikami) znajdują się za witrynami, są szczelnie osłonięte i zabezpieczone. Oświetlenie wystawy uwzględniało koreańskie standardy kuratorskie. Można było o tym przeczytać przed wejściem do sal, co sugeruje, że być może polskie standardy pozwalałyby na nieco jaśniejsze światła.

Opisy poszczególnych eksponatów na wystawie były minimalistyczne: zawierały tylko nazwę artefaktu, materiału i czas, z którego pochodził, oraz numer identyfikacyjny i nazwę muzeum źródłowego. Prawie wszystkie eksponaty pochodziły z Koreańskiego Muzeum Narodowego, ale pokazano także niezwykle cenny parawan z Koreańskiego Muzeum Pałacowego. W każdej sali znajdowały się pergaminy z wyjaśnieniami historycznymi zawieszone na ścianie. Malowane pergaminy 
(a dokładnie - specjalny niepalny papier, który był inspirowany pergaminami) stanowiły także ozdobę całej wystawy. Szczególnie w sali trzeciej kreatywnie wykorzystano je jako tło dla poszczególnych rzeźb Buddy i jednocześnie bardzo ładnie oddzielały część z rzeźbami od części z przedmiotami rytualnymi oraz rękopisami Sutry Lotosu.

\section{Narracja/ Narratologia/ Kultura opowiadania}

Narracje występują nie tylko w książkach i w procesie opowiadania, jesteśmy narracjami otoczeni. Jerzy Trzebiński zauważa:

naturalność formy opowiadania jako środka wyrażania myśli i przeżyć, nie wynika $z$ natury samego procesu komunikacji, lecz jest efektem narracyjnego sposobu pojmowania świata, a sposób ten wynika z narracyjnej struktury ludzkiej wiedzy o świecie (Trzebiński, 2002).

Można jednak - a tutaj nawet trzeba - nazwać i uporządkować otaczające nas narracje, korzystając $z$ doświadczeń interpretowania narracji literackich. Można traktować pojedynczy artefakt w muzeum jako zdanie w narracji (Czermińska, 2018), można badać układ ściany i wzajemne wpływy poszczególnych obiektów, można sprawdzać zależności pomiędzy salami, można patrzeć na wystawę niejako z lotu ptaka i zastanawiać się, jaką całościową opowieść proponuje, czy ma coś, co moglibyśmy odebrać jako fabułę. Możliwości prób odczytania jest bardzo wiele i nawet różne nie wykluczają się nawzajem. Czy jednak czytanie wystawy muzealnej się sprawdza? Co na tej konkretnej wystawie może zauważyć filolog polski, literaturoznawca-obserwator, a nie ekspert koreanista czy muzealnik?

W kontekście wystaw muzealnych, a szczególnie wystaw czasowych, bar$\mathrm{dzo}$ istotnym pojęciem przeniesionym z poetyki jest synekdocha - jeden artefakt, być może nawet szerzej jedna sala muzealna, poświęcona jednemu tematowi, reprezentuje i przedstawia dużo szerszy kontekst kulturowy, z którego pochodzi (w bardziej skrajnych przypadkach - z którego został wyrwany) (Niklewicz, 2015). W przypadku tej wystawy należałoby się zastanowić, czy taka synekdocha nie sprawdziłaby się przy salach z seladonami i porcelaną jedna sala najbardziej reprezentatywnej ceramiki prawdopodobnie wystarczyłaby, aby zaprezentować jej bogactwo i różnorodność. Można jednak to zagadnienie rozszerzyć - przecież cała wystawa jest synekdochą sztuki. A przynajmniej na pewno jej starannie wybranej warstwy - w tym przypadku prezentującej największy splendor i finezję koreańskiej sztuki.

Samej wystawie brakuje pewnych części narracyjnych, które łączyłyby poszczególne sale nie tylko na zasadzie chronologicznej, ale także 
przyczynowo-skutkowej. Oczywiście nie była to wystawa o historii Korei, ale jeśli jej układ budzi poczucie, że niektóre części nie pasują do pozostałych, jest to pewien problem. Można się zastanowić, czy to nie specjalny wybór dynamiki narracji przedstawienia - najpierw pokazywanie (sala pierwsza oraz połowa drugiej), potem opowiadanie (o złotej koronie oraz kulturze buddyjskiej), pokazywanie (ceramika i porcelana) i znów opowiadanie (kultura i sztuka Joseon) - jednak wciąż pewne poczucie ciagłości powinno zostać zachowane.

Brak poczucia ciągłości potęguje fakt, że przejścia pomiędzy poszczególnymi salami nie są subtelne, zasadniczo są to sale $z$ wyznaczonym z góry tematem, który nie łączy się z tym, co było pokazane w sali poprzedniej i co jest w następnej. Nawet jeśli czarno-złota sala-gablota wprowadza pewien podniosły nastrój i królewski klimat, przechodzi się następnie do sali z posągami Buddy, które także są złote, ale klimat powinien zmienić się na bardziej wzniosły czy nawet uduchowiony. Wrażenie może jednak zostać zakłócone $z$ powodu nastroju narzuconego przez poprzednią salę - istnieje szansa, że zwiedzający zwróci większą uwagę na to, że figury są złote, niż na to, że przedstawiają Buddę. Im dłużej też myśli się o planie całej wystawy, tym bardziej ma się poczucie, że sala prezentująca sztukę i kulturę buddyjską do niego nie pasuje.

Ogromny kontrast stanowiło także przejście pomiędzy salami z ceramiką i salami z kulturą i sztuką okresu Joseon. Ceramika opisywana była jako przedstawienie neokonfucjańskich wartości prostoty i umiaru. Przechodząc do sal szóstej i siódmej, zwiedzający mógł się zastanawiać, gdzie te wartości się podziały w kontekście pokazywanego w sali szóstej królewskiego bogactwa. Jest to najbardziej skokowe, jeśli nie wręcz wyglądające na niezaplanowane, przypadkowe przejście na całej wystawie. Przejście pomiędzy salą z rytualnymi naczyniami buddyjskimi i ceramiką było dość naturalne i logiczne, podobne poprzedzono podobnym. Neutralne przejście było pomiędzy salami pierwszą i drugą - chronologiczne.

Dzięki wypowiedzi dyrektora Koreańskiego Muzeum Narodowego wiemy, że wystawa miała wyraźny plan: „Jej scenariusz zbudowano wokół kluczowych zagadnień sztuki koreańskiej, a wystawiane eksponaty unaoczniaja proces rozwoju naszej kultury i cywilizacji na przełomie epok" (Bae, 2019, s. 9). Trzeba się zastanowić, czy wystawa faktycznie unaoczniała proces, czy jedynie oznaczała punkty na linii czasu. Wydaje się, że dominuje ta druga strategia. Szczególnie zauważalnym przykładem był brak wspomnień o Konfucjuszu (na samej wystawie), ale podkreślanie istotnej roli neokonfucjanizmu w sztuce i kulturze koreańskiej. Bezsprzecznie jednak wybrane eksponaty najlepiej obrazowały dany element czy czas sztuki koreańskiej i nie można mieć wątpliwości, że były to zagadnienia najważniejsze. Zwiedzający wychodzący z wystawy 
prawdopodobnie został przekonany, że ceramika i porcelana, wyroby ze złota - wszystko odznaczające się precyzją wykonania i jakością materiałów - a także ogólne poczucie elitarności i królewskości są „kluczowymi zagadnieniami sztuki koreańskiej”.

Dopiero po wyjściu z wystawy można zauważyć, że symbolem długiego trwania kultury Korei wcale nie był element splendoru i finezji, ale element ducha i materii. Gdyby zapytano, co najbardziej uspójnia wystawę, odpowiedź brzmiałaby: kwestie duchowości związane z obrzędami na cześć zmarłych przodków. W większości kultur sprawy te są niezwykle istotne, ale tutaj przyjrzymy się temu, co prezentowano na wystawie. I tak już w pierwszej sali pokazano niezwykły sposób pochówku osób z klasy wyższej - dolmeny. Duża część zabytków prezentowanych na wystawie to przedmioty rytualne odnajdywane w grobowcach. Następnie cała sala poświęcona jest sztuce buddyjskiej - z podziałem na rzeźby i figurki oraz różnego rodzaju naczynia i przedmioty rytualne, ale znajdują się tam także przedmioty składne w grobowcach. Seladony i inne rodzaje koreańskiej ceramiki prezentowane w kolejnych salach znajdowano m.in. w świątyniach przodków dynastii panującej, a naczynia były ozdabiane motywem dziesięciu symboli długowieczności. W sali siódmej zobaczymy np. kolekcję miniaturowych naczyń grobowych z porcelany, ale co istotniejsze - wiele przedmiotów dotyczących neokonfucjańskiego obrządku ku czci przodków, który był niezwykle ważnym elementem kultury. Powiązania ceramiki i wytwórstwa naczyń z życiem duchowym były nierozerwalne zarówno w czasach dolmenów, jak i w czasach dynastii Yi.

\section{Materiały dodatkowe}

Na zwiedzających wystawę czekały dwa rodzaje ulotek, które można podzielić na przeznaczone dla dorosłych i dla dzieci. Ulotki dla dorosłych były wspominane już wcześniej, to one mają na okładkach złotą koronę (ulotka większa) oraz złotego Bodhisattwę Awalokieeśwarę (ulotka mała) i wydają się bardzo eleganckie. W pierwszej znajdują się opisy poszczególnych sal i niewielka ilość informacji, których nie przeczytamy na pergaminach na samej wystawie. Ulotka mniejsza zawiera podstawowe informacje o samej wystawie oraz program wydarzeń towarzyszących.

Dużo ciekawiej prezentują się ulotki z założenia przeznaczone dla młodszych zwiedzających opatrzone tytułem Na tropie... sztuki koreanskiej. Ciekawostki $i$ informacje. Jedna $\mathrm{z}$ nich utrzymana w złoto-czarnej kolorystyce dotyczy, jak łatwo wywnioskować, królewskich aspektów wystawy, na jej pierwszej stronie widzimy rysunek złotej korony. Co jednak różni ją od ulotek dla dorosłych, ale także od opisów zaprezentowanych 
na samej wystawie, to ilość informacji, które zawiera. Na wystawie często wspominana były symbolika zwierząt w kulturze koreańskiej, ale nigdy nie została szczegółowo wyjaśniona. W ulotce znajdziemy wyjaśnienia dotyczące m.in. Feniksa, kota czy smoka. W tych materiałach znajduje się także opis korony z Królestwa Silla, którego to opisu bardzo brakuje na samej wystawie, np. informacji o symbolice powtarzającego się kształtu nerki/przecinka w zdobieniach.

Jeśli porównamy czy zbadamy pewną zależność pomiędzy tym, jak bardzo wystawa promowana była złotą koroną i ile jest o niej informacji na wystawie, a tym, jak niewiele mówiono o kolekcji ceramiki (zajmującej dwie sale), ile zaś szczegółów dotyczących porcelany i rodzajów wazonów jest na wystawie (w postaci papirusów), musi powstać pytanie, z czego ta dziwna dysproporcja wynikała. Czy jest to efekt przygotowania sal - ściany sal z ceramiką były puste, gdyż artefakty prezentowane były na stołach, natomiast złota korona wraz z innymi złotymi przedmiotami miała specjalnie zaaranżowaną połowę sali. To znaczy, że w salach z ceramiką było miejsce na zawieszenie papirusów z opisami, w sali z koroną nie. Może więc przeniesienie wyjaśnień dotyczących korony do ulotek było bardziej koniecznością niż czymś, co chciano robić. Czy może twórcy wystawy zabiegali o estetyczny, widowiskowy efekt korony, niekoniecznie podkreślając jej historyczne znaczenie, czy też zależało im na poinformowaniu, czy nawet doedukowaniu zwiedzających o zabytkach ceramiki i jej znaczeniu w historii Korei. Miałoby to sens, biorąc pod uwagę, że twórcy wystawy (zarówno ze strony koreańskiej, jak i polskiej) mieli na celu, aby Korea przestała kojarzyć się z technologią.

Druga ulotka utrzymana w kolorze nefrytowej zieleni oczywiście nawiązuje do seladonów, ale znajdziemy w niej także dodatkowe informacje o przedstawieniach Buddy i Bodhisattwy. Co jednak najciekawsze, na jej pierwszej stronie zobaczymy linię czasu, która w prosty sposób wyjaśnia chronologię i istotne punkty wystawy.

Wystawę uzupełnia album podzielony na dwie części: Duch $i$ materia oraz Katalog. W pierwszej można przeczytać trzy teksty: Ceramika koreańska, Piękno koreańskiej rzeźby buddyjskiej oraz Konfucjanizm i sztuka Joseon. Katalog poświęcony jest szczegółowemu opisowi samej wystawy. Autorami teksów w albumie są Koreańczycy, chociaż należy zaznaczyć, że teksty te nie były tłumaczone z języka koreańskiego na polski, ale najpierw z koreańskiego na angielski i dopiero $\mathrm{z}$ angielskiego na polski.

Wystawie towarzyszył audioprzewodnik oraz audiodeskrypcje, teraz wszystkie nagrania można znaleźć na stronie muzeum w zakładce multimedia. Nagrań w audioprzewodniku jest 24, audiodeskrypcji - 5. Audioprzewodnik dopowiada wiele informacji, których wyjaśnień brakowało na samej wystawie (np. wspominanej już symboliki zwierząt), ale także 
porusza kwestie religii i przemian wyznań na Półwyspie Koreańskim. Bez tych dodatkowych informacji można by wyjść z wystawy z przekonaniem, że z buddyzmu w Korei narodził się prawie od razu neokonfucjanizm.

Należy także zaznaczyć, że pracownicy muzeum ani nie podpowiadali, ani nie zachęcali do korzystania z audiodeskrypcji/audioprzewodnika dostępnych także na stronie internetowej (ale wypożyczenie audioprzewodnika to dodatkowy zarobek dla muzeum) - czy nawet do sięgnięcia po opisywane ulotki. Zwiedzanie wystawy bez tych dodatkowych opisów i informacji może być trudne, a przecież nie dla wszystkich odwiedzjących wypożyczenie audioprzewodnika będzie czymś intuicyjnym.

\section{Czego brakuje?}

Na żadnej wystawie - bez znaczenia, czy jest to wystawa stała w danym muzeum, czy czasowa - nie można pokazać wszystkiego. Czasami jest to kwestia tematu wystawy, czasami przestrzeni muzealnej. Warto zauważyć także, że wystawy stałe można uzupełniać czy zmieniać. Natomiast wystawy czasowe mogą być pokazywane w różnych miejscach i różnych przestrzeniach, ale raczej nie dodaje się do nich nowych artefaktów. Mają starannie zaplanowany kształt w postaci przedmiotów wybranych do zaprezentowania. Powstaje pytanie: co zostaje odrzucone w procesie kształtowania? Czy można wywnioskować z tego, co jest prezentowane, dlaczego nie ma innych artefaktów i brak jakich przedmiotów „rzuca się w oczy”? Bądź, z nieco innej strony, czego na wystawie brakuje z perspektywy odwiedzającego, a co ułatwiłoby mu odbiór i rozumienie tego, co widzi.

Na omawianej wystawie uwagę szczególnie przykuwają stroje - prezentowane są tylko części wierzchnie, a na dodatek to repliki - jedyne nieoszklone przedmioty na całej wystawie. Widocznym brakiem jest także nieobecność charakterystycznych koreańskich nakryć głowy z epoki Joseon - gat (męskiej) czy hwagwan - kobiecej ozdoby, czegoś w rodzaju korony zakładanej np. na śluby. Zobaczyć można było natomiast szpilki do włosów oraz ozdobne zawieszki norigae. Co ciekawe, w jednej z dziecięcych ulotek można zobaczyć rysunek przedstawiający koreańską królową w oficjalnym stroju.

Można by potraktować pokazanie tylko warstwy wierzchniej ubrań jako metaforę całej tej wystawy, która, prezentując oczywiście bardzo cenne i skrupulatnie wybrane eksponaty, niejako zatrzymuje się tylko po pewnej wierzchniej warstwie tego, co w kulturze Korei ładne i przyjemne. Nie ma jednak wątpliwości, że każdy kraj chce po prostu prezentować to, co ma najlepszego i najpiękniejszego - a szczególnie na tak wyjątkowej wystawie jak ta. 
Pomocna w odbiorze wystawy mogłaby być mapa Korei - na wystawie w Pekinie była mapa Polski - na której zaznaczone byłyby np. miejsca, gdzie odnaleziono eksponaty. Pomogłoby to także lepiej zaprezentować chronologię pewnych zdarzeń historycznych, choćby rozprzestrzeniania się buddyzmu na Półwyspie Koreańskim. Zróżnicowanie regionalne bądź to, że różnego rodzaju zabytki znajdowano na różnych terenach, ale datować można je na podobny okres, jest istotne dla pokazania rozwoju Korei.

Niewspominanie o północy Korei oraz pokazywanie jedynie najlepszych, najpiękniejszych elementów kultury jest swego rodzaju tabuizacją ciemnych kart historii i kultury regionu. Można mieć poczucie, że ogólnie na wystawie prezentowano obraz nieco zbyt piękny (czy może tylko nieco zbyt powierzchowny), aby był prawdziwy. Albo przynajmniej, aby pokazywał całość ducha i materii w sztuce Korei.

$\mathrm{Na}$ samej wystawie nie wspominano o Japonii, ale można usłyszeć o niej dwa razy w audioprzewodniku. Więcej o wpływach Japonii na Koreę można przeczytać w albumie, ale relacje pomiędzy tymi krajami wciąż są na tyle skomplikowane, że niezaskakujące jest ograniczenie odwołań do Japonii na wystawie, a także niewspominanie o całym XX w. Jednocześnie naprawdę trudno oczekiwać, żeby strona koreańska przygotowała na wystawę coś, czego nie posiada, gdyż zbiory koreańskiego muzeum obejmują czas do $1910 \mathrm{r}$.

\section{Podsumowanie}

Po pierwsze, na wystawie prezentowany jest obraz jednej Korei - obejmuje ona historię kraju sprzed podziału, a o samym podziale na wystawie także się nie dowiemy. To zmienia prawdopodobnie najpopularniejszą (najbardziej obecną w mediach) optykę (czy kontekst) pojawiania się Korei w Polsce, tj. pryzmat polityczny. Jeśli przyjrzeć się, ile jest w mediach informacji na temat Korei Północnej, a ile na temat Południowej-dysproporcja jest przerażająca. Możliwe także, że pierwszym skojarzeniem ze słowem Korea jest Korea Północna. Pewien unifikujący charakter wystawy podkreśla, że podział Korei jest czymś nienaturalnym i cały obszar Półwyspu Koreańskiego to jeden kraj ze wspólną historią i kulturą.

Po drugie, jeśli zapytamy, jakie wartości niesie wystawa, odpowiedź bez wątpienia musi brzmieć: wartości neokonfucjańskie, chociaż na wystawie brakuje informacji o samym Konfucjuszu.

Inną ciekawą rzeczą, którą można wywnioskować z planu wystawy, jest pewne poczucie falowości kultury bądź tego, co w danym momencie historycznym było istotne. Wręcz kontrastowe przeplatanie się prostoty (wynikającej albo z historii, albo świadomej decyzji, że ceramika 
ma być prosta) i bogactwa (to zdecydowanie świadome podkreślanie statusu). Ostatecznie bogaty, złoty, arystokratyczny obraz zostanie ze zwiedzającymi prawdopodobnie dłużej ze względu na artefakty pokazywane w dwóch ostatnich, bez wątpienia najistotniejszych salach. Ale także pierwszy naprawdę intrygujący przedmiot na wystawie, wykorzystywany $\mathrm{w}$ materiałach marketingowych, to nic innego jak złota korona. Wracając na moment do wartości neokonfucjańskich, u odbiorcy wystawy może pojawić się pytanie, jakim sposobem godzono je z bogactwem arystokracji.

Co więcej, momentami można odnieść wrażenie pewnej przypadkowości wystawy - granica przebiega pomiędzy salą trzecią i piątą. W salach I-III panuje wyraźny układ chronologiczny, w sali V/IV (ze względu na budowę muzeum) następuje przeskok. I chociaż z jednej strony i w jednej, i w drugiej sali są naczynia, to znacząco zaburzone zostaje poczucie chronologii, które już nie powraca do ostatniej sali. Daje to efekt - bardzo wzmocniony układem sal wystawienniczych - sklejenia dwóch osobnych, niepowiązanych ze sobą części.

Można spojrzeć na wystawę, czy raczej na założenia jej twórców, z jeszcze jednej strony. Mianowicie dyrektor zarówno polskiego muzeum, jak i koreańskiego oraz kuratorzy podkreślali chęć pogłębienia znajomości w Polsce kultury Korei także poprzez budowanie paralel. Wydaje się jednak, że pominięto tu pewien fakt - istotne formy koreańskiej państwowości rozwijały się w I w. p.n.e., mniej więcej wtedy też powstawały piękne złote posagi Buddy. O polskiej państwowości mówi się od X w. naszej ery. Myślę, że warto nie zgubić tego kontekstu, nawet jeśli Polską historię od XVIII w. i dwudziestowieczną historię Korei łączą podobne wydarzenia.

Jeśli przyjmiemy, że stereotypowo kraje Azji Wschodniej postrzegane i prezentowane są w mediach jako dziwne, to pokazanie takiej historycznej (gdyby przyjąć pewien punkt widzenia - normalnej) wystawy na pewno przyczynia się do edukacji i budowania obrazu Korei Południowej nieopartego na dziwności i egzotyzacji. Bo niestety przykładowo kolejne pozycje wydawnicze takie jak Nunchi. Koreański sekret dobrych relacji z ludźmi sugerują, że być może kulturę Korei Południowej niedługo będziemy traktowali jako nowe hygge.

Czy świadomość ograniczeń, jakie niesie ze sobą ta wystawa (zaczynając od ograniczeń związanych ze zbiorami koreańskiego muzeum, kończąc na możliwościach przestrzennych polskiego), uzasadnia niezastanawianie się, co można było zrobić lepiej? I tak, i nie. Odbiorca wystawy wcale nie musi zdawać sobie sprawy z tych ograniczeń, ale może oczekiwać bardziej całościowego ujęcia tematu sztuki Korei, nawet jeśli zamkniętego w nazwie Splendor i finezja. Duch i materia w sztuce Korei. Tu pokazano tylko to, co najlepsze. 


\section{Bibliografia}

Bae, K. (2019). Przedmowa w Splendor i finezja. Duch i materia w sztuce Korei. Muzeum Narodowe w Warszawie.

Bojarska-Cieślik, J. Splendor i finezja. Duch i materia w sztuce Korei. Pozy-

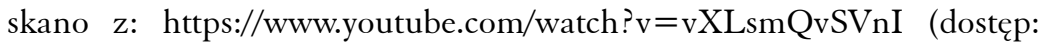
3.07.2020).

Burdelski, M. (2021). Korea w oczach Polaków. Gdańsk: Wydawnictwo Uniwersytetu Gdańskiego.

Citko, M.K. (2011). „Kraj Kwitnącej Wiśni” czy „kraina kosmitów”? Wizerunek Japonii w polskich mediach. Media i Medioznawstwo nr 4. Pozyskano z: polska-azja.pl, http://www.polska-azja.pl/wp-content/uploads/2012/10/ Kraj-Kwitnacej-Wisni-czy-kraina-kosmitow.-Wizerunek-Japonii-w-polskich-mediach_M.Citko_.pdf (dostęp: 16.09.2020).

Czermińska, M. (2018). Kategorie poetyki w czytaniu przestrzeni muzealnych. Biatostockie Studia Literaturoznawcze, 13/2018. DOI: 10.15290/bsl.

Doroszewski, W. (red). Stowikjezzyka polskiego. Pozyskano z: http://doroszewski.pwn.pl/ (dostęp: 16.09.2020).

Gieysztor, A. (1994). Historical Similarities Between Poland and Korea. Korea Observer 3/25. Pozyskano z: http://koreaobserver.or.kr/html/? pmode $=$ sub page\&smode $=$ archive $($ dostęp: 23.02.2021).

Goban-Klas, T. (2006). Korea. Historia i wspótczesnošć. Toruń: Wydawnictwo Adam Marszałek.

Keum, J.-T. (2014). Historia koreańskiej mysli konfucjańskiej. Skarżysko-Kamienna: Kwiaty Orientu.

Miziołek, J. (2019). Przedmowa w Splendor i finezja. Duch i materia w sztuce Korei. Muzeum Narodowe w Warszawie.

Niklewicz, B. (2015). Język muzeum, czyli o nowych sposobach odczytywania wystaw. Polonistyka. Innowacje, nr 2. DOI: 10.14746/pi.

Rurarz, J. (2009). Historia Korei. Warszawa: Wydawnictwo Akademickie Dialog.

Świecimski, J. (1994). Ekspozycja muzealna jako dzieło sztuki. Muzealnictwo, 34. Pozyskano z: http://bazhum.muzhp.pl/media//files/Muzealnictwo/Muzealnictwo-r1992-t34/Muzealnictwo-r1992-t34-s38-51/Muzealnictwo-r1992-t34-s38-51.pdf (dostęp: 02.04.2020).

Trzebiński, J. (2002). Narracyjne konstruowanie rzeczywistości. W J. Trzebiński (red.), Narracja jako sposób rozumienia świata. Gdańsk: GWP. Pozyskano z: https:/www.researchgate.net/publication/259495267_Narracja_ jako_sposob_rozumienia_swiata (dostęp: 22.09.2020).

Yaxi Liu (2000). Museum Narration: A Memory-Driven Storyscape. W Kaby Wing-Sze Kung (red.), Reconceptualizing the Digital Humanities in Asia, New Representations of Art, History and Culture. Singapore: Springer.

Zespół kuratorski, ulotki wystawy. 
Żygulski, Z. (1990). Założenia teoretyczne wystawiennictwa muzealnego w świetle osiągnięć współczesnej nauki. Muzealnictwo, 33. Pozyskano z: http://bazhum.muzhp.pl/media//files/Muzealnictwo/Muzealnictwo-r1990-t33/Muzealnictwo-r1990-t33-s3-11/Muzealnictwo-r1990-t33-s3 -11.pdf (dostęp: 02.04.2020).

Poprzęcka, M. (2015). Sztuka polska na Dalekim Wschodzie. Wystawy „Skarby z kraju Chopina” w Muzeum Narodowym Chin w Pekinie i „Sztuka polska - niezłomny duch” w Muzeum Narodowym Korei w Seulu. Rocznik Muzeum Narodowego w Warszawie, Seria Nowa, 4/40. Pozyskano z: http://archiv.ub.uni-heidelberg.de/artdok/5154/1/Poprzecka_Sztuka_polska_na_Dalekim_Wschodzie_2015.pdf (dostęp: 26.02.2021).

Klaudia Golon - absolwentka Wydziału Filologicznego Uniwersytetu Gdańskiego, pod kierunkiem dr hab. Magdaleny Horodeckiej przygotowała rozprawę magisterską poświęconą reprezentacjom Korei we współczesnej kulturze polskiej. Absolwentka kierunku zarządzanie instytucjami artystycznymi. Szczególnie bliskie jej są zagadnienia edytorsko-redaktorskie. Licencjat poświęciła sposobom zapisu koreańskich nazw własnych w książkach wydawanych w języku polskim. 